\title{
14. DISTINCTIVE FEATURES OF MUSIC EDUCATION IN IAŞI: AN OVERVIEW AFTER 155 YEARS
}

\section{Laura Otilia Vasiliu ${ }^{152}$}

\begin{abstract}
Over a century and a half after the establishment of the first state educational institution dedicated to music in Iaşi - the School of Music and Declamation (1860) - the distinctive features of music education and the social and cultural phenomena involved can be perceived and analyzed. This study provides arguments to support the following features: 1. the openness to assimilate a variety of pedagogic and cultural influences, both from Europe and from Romania; 2. the role played by leading personalities, musicians - professors, in rising performance levels and in perpetuating the project; 3. valorizing Romanian music traditions - liturgical songs of Byzantine origin and regional folklore - through education (specializations, courses, creative activities and music performance); 4 . the constant involvement of music education in concerts and musical performances in Iaşi.
\end{abstract}

Key words: Music education; Iaşi; pedagogical influences; Romanian musical traditions; musicians of Iaşi

\section{Introduction}

The historical research of music education in Iaşi has a deep-rooted tradition. In the beginning, it was Teodor T. Burada (considered to be the first Romanian musicologist) who, in significant studies ${ }^{153}$ published in the $8^{\text {th }}$ and $9^{\text {th }}$ decades of the $19^{\text {th }}$ century, described the School, later the Conservatory of Music and Declamation, within the cultural ambience of the city of Iassi in those times. The rigorous and objective Annual written by Alexandru Aurescu în $1905^{154}$ was also of cardinal importance in this respect. This volume was meant to be part of the work of the National Exhibition organized in 1906 to celebrate 40 years of the reign of King Carol I of Romania, to show "the progress made by the Romanian people under his happy and wise reign"155.

The ambitions and the accomplishments of music education in the city of Iassi of the first half of the $20^{\text {th }}$ century and of the following decade were recorded by the professor and musicologist George Pascu, who produced scientific and cultural well-founded research dedicated to the Conservatory upon celebrating 100 years of existence ${ }^{156}$. The events that followed were recorded by Professor Mihail Cozmei, who published successive volumes on this topic up to $2010^{157}$. The research which focused on the history of the institution can be

\footnotetext{
${ }^{152}$ Professor PhD, "George Enescu” University of Arts from Iaşi of Romania, email: otiliastrug@yahoo.com

${ }^{153}$ Conservatorul de muzică din Iaşi , 1875; Conservatorul de muzică şi declamaţiune din Iaşi, 1976 Cercetări asupra Conservatorului filarmonic-dramatic din Iaşi (1936-1938) , 1888

${ }^{154}$ Alexandru Aurescu, Anuarul Conservatorului de muzică şi declamaţie din Iaşi. De la înfiinţarea lui până la 1905, Iaşi, Tipografia H.Holdner, 1906

${ }^{155}$ Idem, p. 1

${ }^{156}$ George Pascu, 100 de ani de la înfiinţarea Conservatorului ,, George Enescu’'Iaşi (1864-1964)

${ }^{157}$ Mihail Cozmei, 125 de ani de învăţământ artistic de stat (1860-1985); Pagini din istoria învăţământului artistic din Iaşi (1960-1995);Pagini din istoria învătământului artistic modern din Iaşi la 150 de ani, Editura Artes, 2010
} 
correlated with and complemented by the information published in books dedicated to music issues, periods and personalities in Iaşi. ${ }^{158}$

This study is based on personal research, valorized firstly (2009) in the broadcasting of 12 radio programs under the slogan Iassi, people and music ${ }^{159}$, secondly by dictionary articles (2014-2015), published (or in the process of being published) in Grove Music Online ${ }^{160}$, and thirdly by participating as coauthor in creating the monographic volume 155 Years of Modern Artistic Education in Iaşi ${ }^{161}$. In this article, I intend to identify and to argue the distinctive features of the school of music of Iaşi, which are formulated as premises for research, as follows:

1. openness to assimilate a variety of pedagogic and cultural influences, both from Europe and from Romania;

2. the role played by leading personalities, musicians - professors, in rising performance levels and in perpetuating the project;

3. valorizing Romanian music traditions - liturgical songs of Byzantine origin and regional folklore - through education (specializations, courses, creative activities and music performance);

4. the constant involvement of music education in concerts and musical performances in Iaşi.

\section{Openness to assimilate a variety of pedagogic and cultural influences, both from Europe and Romania}

\subsection{Premises for establishing Western-style music education in Iaşi}

It may seem surprising to the Romanian researchers today that, in a city with a deep-rooted tradition of Byzantine religious music schooling (The Vasilian College attached to the Three Hierarchs Monastery, 1640, Seminar from Socola, 1802), and in a city placed under Phanariote rule for a century (1711-1821), thus cultivating the Turkish-Greek court music, as well as Gypsy fiddler music, the first European music institution - The Philharmonic Dramatic Conservatory - was already established in 1836, followed by The School of Music and Declamation in 1860.

\footnotetext{
${ }^{158}$ George Pascu; Iosif Sava, Muzicienii Iaşului [Musicians of Iasi], Editura muzicală, 1987; George Pascu; Melania Boțocan, Hronicul muzicii ieşene [Chronicle of Music in Iasi], Editura „Noël”, 1997; Mihail Cozmei, Existenţe şi impliniri. Dicţionar biobibliografic. Domeniul muzică [The Existence and Fulfillment. Bibliographical Dictionary. Music Field] Editura Artes, 2005, 2010; George Pascu, Din dragoste de oameni şi de muzică. 14 convorbiri moderate de Mihail Cozmei şi Dora-Maria David [Out of Love for People and Music. 14 conversations moderated by Mihail Cozmei and Dora-Maria David], Editura Artes, 2015

159 Project in collaboration with Radio România Muzical, Radio Iaşi, UAGE, see http://www.romaniamuzical.ro/emisiuni/iasi/arhiva-emisiuni.html

${ }_{160}$ Published articles: „Iaşi”;”Musicescu, Gavriil” (in collaboration); „Spătărelu, Vasile” (in collaboration); „Pautza, Sabin” (in collaboration)”; Munteanu, Viorel” - see http://www.oxfordmusiconline.com. Articles in the process of being published: Cortez, Viorica; Universitatea de Arte "George Enescu" Iaşi ["George Enescu" University of Arts, Iaşi]; The Romanian Opera of Iasi

Grove Music Online. Oxford Music Online. Oxford University Press. Web. 14 Nov. 2015. $<\mathrm{http} / / / \mathrm{www} .0 x$ fordmusiconline.com/subscriber/article/grove/music/40385>.

${ }_{161}$ Atena Elena Simionescu (editor), 155 ani de invătăământ artistic modern la Iaşi. Partea I, 1930-1950.Partea a II-a, 1950-2015 / 155 years of modern artistic education in Iaşi.Part I, 1830-1950. Part II. 1950-2015 [155 years of Modern Artistic Music Education in Iaşi. Part I, 1930-1950. Part II 1950-2015 / 155 years of modern artistic education in Iaşi], Editura Artes, 2015
} 
The cultural mutation produced in the middle of the $19^{\text {th }}$ century can only be explained by taking into account several coexisting phenomena, the effects of which have lingered for a long time in the background. I am referring first of all to the constant influence of Polish Catholicism ${ }^{162}$ and to the introduction of German Protestantism (Schola latina from Cotnari, 1563). To the same extent, the neighboring Russian culture became, at the beginning of the $18^{\text {th }}$ century (1711 - the visit of Tsar Peter the Great to Iaşi), a means by which European cultivated music ${ }^{163}$ was able to penetrate Romania. The French and Italian immigrants who settled in Iaşi after 1800 (also in the aftermath of the terror of the French Revolution), who included trained musicians ${ }^{164}$, some of whom become professors of music for the boyars, also played a fundamental role.

Thus, in 1835, when, "at Mihai Sturza's Royal Court, everyone spoke French" ${ }^{165}$, the first higher education institution, the Michaelian Academy, was established. The importance of the geographical position of the city of Iaşi and of its historic evolution in this spectacular assimilation of European culture was generally recognized. Being located at the crossroads leading from West to East, the city of Iaşi was visited by countless musicians, theatre and opera companies, its capacity as capital city throughout 3 centuries (1564 - 1862) favoring economic and cultural growth as well as the creation of a class of enlightened boyars. Thus, in the first half of the $19^{\text {th }}$ century, the city of Iaşi had an educated society that valued music and that had already developed a taste and a scene for concerts $^{166}$.

\subsection{The music conservatory in the $19^{\text {th }}$ century - reuniting different European schools}

The most eminent professors of the Conservatory were trained in various European schools, creating a concentrated construct of cultures and teaching methods that were adopted in Iaşi by a successive series of graduates in the first 4 decades of its existence. The content of the teaching activity, the musical repertoire and the artistic activities of the students reflect the intermixture or alternation of the German school of Berlin and Frankfurt (Eduard Caudella), the French school from Paris (Eduard Caudella, Teodor T. Burada, Titus Cerne), H.Vieuxtemps's Franco-Belgian violin school (Eduard Caudella), the Italian school of singers and wind instruments (Pietro Mezzetti, Enrico Mezzetti, Alfonso Cirillo, Antonio Cirillo, Carlo Cirillo), the Russian St. Petersburg composition school (Gavriil Musicescu), the Polish piano school from Lvov (Constantin Gros - Carol Miculi's student).

\footnotetext{
162 "The Polish Catholic influence, through the Jesuits school, was useful for us, setting the scence for the appearance of the great chroniclers Grigore Ureche, Miron Costin, Ion Neculce and, through the accent placed on education, an elite of highly educated people was formed in Iaşi”, in Melania Boţocan; George Pascu, Hronicul muzicii ieşene, [Chronicle of Music in Iasi], Editura "Noël", 1997, p.16

${ }^{163}$ The European Russian culture was propagated in Iaşi also due to periods of Russian military domination: September 1769 - January 1775; October 1788 - March 1792; November 1806 - May 1812; April 1828 - April 1834 - see https://ro.wikipedia.org/wiki/Lista_domnilor_Moldovei\#Secolul_al_XVIII-lea

${ }^{164}$ Melania Boţocan; George Pascu, op.cit, p. 33

${ }^{165}$ Idem, p.33

${ }^{166} \mathrm{Idem}, \mathrm{p} .54$
} 


\subsection{The period from 1900 to 1950 - balance between professors trained in}

Iaşi and Bucharest, and specialized abroad

The phenomenon of absorbing diverse educational and cultural experiences is highlighted in the training of musicians-professors in the first half of the $20^{\text {th }}$ century. Unlike the previous period, they were first graduates of the Conservatories of Iaşi and Bucharest, most of whom continued their studies in various European music centres.

\section{PROFESSORS-GRADUATES OF THE IASSI CONVERVATORY}

- Aspasia Sion-Burada (piano,1889-1932) - Iaşi, Vienna (Leschetizky), Leipzig

- Atanasie Theodorini (violin, 1901-1926) - Iaşi, Berlin (J. Joachim), Vienna

- Sofia Teodoreanu (theory and solfeggios, cor - 1903-1924) - Iaşi

- Enrico Mezzetti (piano, 1906-1930) - Iaşi, Italy

- Alexandru Zirra (harmony, 1907-1925; 1931 - 1945) - Iaşi, Italy

- Antonin Ciolan (harmony, counterpoint, orchestra, choir - 1912-1913; 19191921; 1926-1946) - Iaşi, Berlin, Leipzig, Dresda

- Mircea Bârsan (violin, 1926-1945 Iaşi, Paris

- Ion Ghiga (harmony, counterpoint, music encyclopedia, chamber music 1928-1933 - Iaşi, Bucharest, Berlin, Paris

- Radu Constantinescu (piano, 1931-1950) - Iaşi

- Eliza Ciolan (piano, 1932-1949) - Iaşi, Vienna (Weingartner), Paris (Cortot)

- Mansi Barberis (singing, 1934-1950) - Iaşi, Berlin, Paris.

PROFESSORS-GRADUATES OF THE BUCHAREST CONVERVATORY

- Nicolae Theodorescu (cello, 1909-1939) - Bucharest

- Ilie Ionescu-Sibianu (piano, 1908-1919; 1924-1934) - Bucharest, Vienna

- Gogu Ionescu (clarinet, 1913-1938) Bucharest

- Carol Nosec (theory and solfeggios, orchestra - 1924-1945) - Bucharest

- Ludwig Acker (violin, 1924-1950) - Bucharest, Iaşi, Vienna

- Gavriil Galinescu (theory and solfeggios, folklore, Byzantine music - 1935 1948) - Bucharest, Leipzig, Vienna

- Rodica Nestorescu (singing, 1924-1941) - Bucharest

- Vasile Rabega (singing, 1930-1950) - Bucharest

- Nicolae Brosteanu (clarinet, 1938-1950) - Bucharest

- Hristache Popescu (flute, 1924- 1950; 1968-1973) - Bucharest, Iaşi

- Constantin Georgescu (counterpoint, harmony, composition - 1924-1950) Bucharest, Paris

\subsection{The period from 1960 to 1990 - a national complex of educational cultures}

The activity of the conservatory ceased in the decade 1950-1960, only to be resumed in the form of a reconstruction borne by the rector Achim Stoia. The new specialized staff reunited a variety of Romanian schools and styles of musical education in Iaşi. The teaching staff comprised:

a. Professors trained in Iaşi before 1950, some of whom underwent specialized training abroad: George Pascu (history of music, from 1943); Constantin Constantinescu (theory and solfeggios, 1943); Florica Niţulescu 
(piano, Vienna, from 1946); Ella Urmă (singing, from 1946); Nicolae Marcovici (piano, Paris, from 1960); Alexandru Garabet (violin, Prague, from 1960); Vasile Dumitriu (clarinet, from 1963);

\section{b. Graduates of the Bucharest Conservatory -}

- coming from Bessarabia and Northern Ukraine (Russian or Central European school): Alexandra Grozea (singing, Chişinău, Bucharest, Milan, from 1960); Ion Pavalache (choral conducting, Chişinău, Bucharest, from 1960); Gheorghe Sârbu (violin, Chişinău, Bucharest, from 1963), Leonid Popovici (violin, Chişinău, Iaşi, Bucharest, from 1964).

- coming from other Romanian provinces (Ardeal, Banat): Achim Stoia (harmony, from 1942); Ion Baciu (orchestra ensembles, from 1962); Anton Zeman (harmony, from 1964); Sabin Pautza (harmony, orchestration, from 1965); Vasile Spătărelu (counterpoint, musical forms, from 1964); Gheorghe Rus (cello, from 1963).

- From Iaşi/Moldova - graduates of the Bucharest conservatory: Mihail Cozmei (history of music, from 1961), Gabriela Ocneanu (history of music, from 1963); Iulia Bucescu (theory and solfeggios, Bucharest, from 1961), Adrian Diaconu (theory and solfeggios, from 1963), Elena Cozmei (scores reading, from 1964), Cornelia Diaconu (scores reading, from 1964); Ioan Welt (piano, from 1965), Vasile Tarnavschi (piano, from 1968), Liliana Gherman (musical forms, from 1968); Costache Creangă (oboe, from 1963).

- alţi absolvenţi ai conservatorului din Bucureşti: Mircea Dan Răducanu (pian, din 1961); Gheorghe Ciobanu ( folclor, 1965-1972);

c. Graduates of the Cluj Conservatory: Tiberiu Popovici (singing, from 1960); Ştefan Lory (violin, from 1965); Gaspar Markoş (violin, from 1970); Ioan Husti (theory and solfeggios, from 1968; Silviu Varvaroi (double bass, from 1961); Ioan Goia (clarinet,1960);

d. Graduates of the Iaşi Conservatory starting with 1965: Nicolae Gâscă (history of music, choral conducting, from 1965); Visarion Huţu (singing, from 1966); Larisa Agapie (Iaşi, from 1969); Melania Boţocan (Iaşi, from 1966), Paula Bălan (from 1968), Corneliu Vieru (Iaşi, from 1965);

e. Other cases: Pavel Delion (folklore, Cernăuţi, Timişoara, from 1960); Sofia Cosma (piano, Riga, Saint Petersburg, Vienna, from 1970)

3. Role played by leading personalities, musicians - professors, in rising performance levels and in perpetuating the project

A look at the music education in Iaşi reveals the fact that leading musicians/professors played a more important role, over time, in configuring and continuing the development of the school, than the national, ministerial or local authorities, the overall value of teaching staff ensembles, or the organizational capacity of the directors.

Among the most representative personalities in the field from the $19^{\text {th }}$ and $20^{\text {th }}$ centuries - Teodor T.Burada, Constantin Gros, Eduard Caudella, Gavriil Musicescu, Enrico Mezzetti, Antonin Ciolan, Constantin Georgescu, Florica Niţulescu, Constantin Constantinescu, Achim Stoia, George Pascu, Gheorghe Sârbu, Ella Urmă, Ion Baciu, Mihail Cozmei, Florian Simion, Vasile Spătărelu, 
Nicolae Gâscă, Sabin Pautza, Viorel Munteanu, Bujor Prelipcean, Dan Prelipcean etc. - only the ones marked in bold also held positions of director/rector of the institution. In what follows, I will present the main directions of music education initiated by each of the ones listed above.

Teodor T. Burada (1839-1923) initiated historiographical, folklore, byzantinological research, and musical critical writing. His disciples and successor include Titus Cerne and George Pascu.

Constantin Gros (1838-1896) configured the piano school from Iaşi. His students include Aspasia Sion (his successor to the chair), Carol Frühling (pianist, composer and professor in Vienna), and Emil Weitzecher (professor at the Conservatory of Cernăuţi) ${ }^{167}$.

Eduard Caudella (1841-1924) created the violin school in Iaşi, taught violin for 4 decades (1861-1901) and some of his students include Athanasie Theodorini, Mircea Bârsan (professors in Iaşi), Jean and Constantin Bobescu, George Pascu and, episodically, George Enescu ${ }^{168}$.

Gavriil Musicescu (1847-1903), in his capacity as professor of harmony and choral ensemble, founded the school of choral music composition and performance. He created a strong tradition in Iaşi and in Romania through his students - Alexandru Zirra, Antonin Ciolan, Ion Vidu, Timotei Popovici, etc.

Enrico Mezzetti (1870-1930), composer, singing and piano professor, conductor, has exceptional merits in the development of the school of singing (initiated by his father, Pietro Mezzetti). The famous tenor Dimitrie Onofrei was one of his students. In his capacity as Director of the Conservatory, he succeeded in organizing the first season of symphony concerts in Iaşi ( 1905-1907).

Antonin Ciolan (1883-1970), in his capacity as professor of choral and instrumental ensemble, of conductor of "George Enescu Society" orchestra, he established the symphonic orchestra of the Conservatory and created the conducting school, Dinu Niculescu, Emanuel Elenescu, Carlo Felice Cillario, Remus Tzincoca, Radu Botez, George Pascu, Florica Dimitriu (to whom the students of the Cluj Conservatory are added - Petre Sbârcea, Emil Simon, Ervin Acel $)^{169}$ being some of his disciples.

Constantin Georgescu (1895-1960) inaugurated both the teaching of musical composition in Iaşi, drawing up the first treaty (harmony, counterpoint and composition), as well as the history of music, reconfirming the tradition of encyclopedic lectures in Iaşi.

Florica Nitulescu (1897-1988) continued the same pianistic education mastery of her professor, Aspasia Sion-Burada, advocating for refinement, performance, artistic and interpretative elitism. The pianists and professors Ioan Welt, Steluţa

\footnotetext{
${ }^{167}$ Cf. Atena Elena Simionescu (editor), 155 ani de învățământ artistic modern la Iași. Partea I, 1930-1950/155 years of modern artistic education in Iaşi. Part I, 1830-1950., chapter "Arte muzicale" [155 years of Modern Artistic Education in Iaşi. Part I, 1930-1950/155 Years of Modern Artistic Education in Iaşi. Part I, 1830-1950., chapter "Musical Arts" (authors: Carmen Chelaru, Laura Vasiliu and Dalia Rusu-Persic), Editura Artes, 2015, p. 25

${ }^{168}$ Idem, p. 21

${ }^{169} \mathrm{Idem}$, p. 51
} 
Diamant-Dumea, George Rodi-Foca and Vasile Tarnavschi were some of her students.

Constantin Constantinescu (1903-1985) renewed the principles and methods of teaching Theory and Solfeggio. He continued the school of music theory of Iaşi (Sofia Teodoreanu's class), establishing the school of future generations through his students, among whom were the professors Iulia Bucescu, Adrian Diaconu, Viorica Uncheșel and Ioan Diaconu.

Achim Stoia (1910-1973), a composer, conductor, professor, who is going to be remembered in history for performing a difficult mission, namely that of rebuilding the music higher education institution, as Rector, after interrupting his activity in 1950-1960.

George Pascu (1912-1996) created the history of music course, as a fundamental subject, being at the same time the first professor of musicology in the new specialty (1976). Melania Boţocan, Paula Bălan, Laura Vasiliu are some of his disciples and successors.

Gheorghe Sârbu (1916-1997) was the founder of the modern school for violin (alongside Leonid Popovici), being succeeded as chair by Anton Diaconu and Bujor Prelipcean, his disciples.

Ella Urmă (born in 1920) was the chair of the singing department for over 20 years (1963-1984), training many successful performers, among whom the sopranos Maria Boga-Verdeș, Andreea Lory, Adriana Severin, and the mezzosopranos Mihaela Agachi and Mariana Cioromila.

Ion Baciu (1931-1995) reformed the student symphony orchestra, Orchestra Super, beginning with 1968. The success of the concerts performed in Bucharest in the period from 1969 to 1971 represents a major landmark in the history of the institution.

Mihail Cozmei (born in 1931), a musicologist, professor of Romanian music history, had exceptional merits in his capacity as head of the institution (1973$1974 ;$ 1976-1984), by initiating important artistic activities that led to a greater openness of the educational program: Romanian Music Festival (1973); Musical Holidays in Piatra-Neamt (1973).

Iulia Bucescu (1935-2015), professor of theory and solfeggio, developed the principles of Constantin Constantinescu's school, contributing new methods of achieving performance in the field. The current professor George Duţică, $\mathrm{PhD}$, is one of his students who continues to expand his ideas.

Florian Simion (born in 1937), an instrumentalist, professor, conductor, created the percussion class, and developed the field to meet contemporary standards. $\mathrm{He}$ founded the percussion ensemble Alternance (1993), developing an extensive repertoire and obtaining outstanding artistic achievements.

Vasile Spătărelu (1937-2005), a talented composer and professor, set up the composition school within the Iaşi Conservatory, starting with 1971, training the likes of Viorel Munteanu, Teodor Caciora, Cristian Misievici, Leonard Dumitriu.

Nicolae Gâscă (n. 1942) created a modern choral conducting school, cultivating an extensive stylistic repertoire, both in class as well as in his interpretive 
activity, as conductor of the choir Cantores (established in 1976), a musical ensemble with an impressive track record.

Sabin Pautza (born in 1943), an extremely inspired musician, composer, conductor and professor, created an important opening towards modernity in the schools of Iaşi.

Viorel Munteanu (born in 1944), a composer, musicologist, professor, has considerable merits in developing artistic education in Iaşi and its relationship with the media, with personalities from Romania and abroad, in his capacities as Dean and Rector (2000-2012).

Bujor Prelipcean (born in 1948) and Dan Prelipcean (born in 1951), instrumentalists, professors and members of the famous quartet Voces, created the school of chamber music of Iaşi, forming highly successful career ensembles, i.e. Ad Libitum, Gaudeamus, Giocoso string quartets, etc.

4. Valorizing Romanian music traditions - liturgical songs of Byzantine origin and regional folklore - through education (specializations, courses, creative activities and performance)

The emergence and development of the music school in Iaşi reflected proWestern orientation and the will to assimilate European art in musical composition and interpretation. This phenomenon is also reflected in the manner in which Romanian, religious and secular traditions were valorized. The entire $19^{\text {th }}$ century was marked by the phenomenon of valorizing the two archaic sources through harmonic-polyphonic writings and choral interpretation.

Taking the first church choir established in 1814 at the "Vasilian" Gymnasium and "Veniamin Costachi" Seminary as an example of will and kievan influence, the musician and professor Gheorghe Burada stands out as a pioneer of the harmony church repertoire (through his qualities as conductor of the choir of the Conservatory and of the Metropolitan Cathedral, between 1864 and $1870^{170}$. The professor Gheorghe Dima (1870-1877), originally a chanter, continued, the climax being reached by Gavriil Musicescu, not only through his work as a composer and conductor of the Metropolitan Choir (1876-1903), but also as professor of choir and choral singing, starting with $1877^{171}$. Musicescu established a new tradition in choral folk song processing, initiating modal harmonization.

As an echo of the development of folklore and ancient music research in the major European conservatories, Psaltic Folklore and Music (as optional courses) were introduced in Iassi in first decade of the $20^{\text {th }}$ century, with the support of Gavriil Galinescu ${ }^{172}$, more particularly in the period from 1935 and $1948^{173}$.

\footnotetext{
170 Mihail Cozmei, Existenţe şi împliniri. Dicţionar biobibliografic. Domeniul muzică, [The Existence and Fulfillment. Bibliographical Dictionary. Music Field], Editura Artes, 2010, p.64

${ }^{171}$ Alexandru Aurescu, Anuarul Conservatorului de muzică şi declamaţie din Iaşi. De la înfiinţarea lui până la 1905 [Conservatory's Yearbook of Music and Declamation in Iaşi. Since its Foundation until 1905], Iaşi, Tipografia H.Holdner, 1906, p.205

172 Gavriil Galinescu (1883-1960) was a theologian and musician, who studied at the Bucharest Conservatory and trained with great European musicologists and professors, in Leipzig with Arnold Schering, Hugo Riemann and in Vienna, with Egon Wellesz

${ }^{173}$ Mihail Cozmei, op.cit., p.202
} 
During the communist period, the academic level of the two courses (i.e. Folk Music and Byzantine Paleography) was increased through the efforts of professor and researcher Gheorghe Ciobanu, who was employed in Iaşi in the period from 1965 until 1971, when he founded the school of ethnomusicology in Iaşi, represented by Larisa Agapie, Florin Bucescu and Viorel Bârleanu. In the contemporary period, the tradition of the Byzantine music was recovered through the dialogue between theoretic research and monad psaltic music performance, within the study program "Religious Music", established in 1992.

\section{The constant involvement of music education in concerts and musical performances in Iaşi}

Until the establishment of Moldova Philharmonic (1942) and of the Opera (1957), the musical life of the city of Iaşi was supported by the students and professors of the conservatory: apart from the concerts and performances held by artists who were on tour, by orchestras gathered ad hoc to perform at the Great Theatre from Copou (after 1846), at the National Theatre (starting with 1896), at the Tătăraşi Athenaeum (since 1919), by the exceptional, but shortlived (1917-1923) activity of the symphonic orchestra of the "George Enescu" Society, by the artistic performances taking place in boyar halls, continued until the middle of the $20^{\text {th }}$ century.

The initial climax of the institution's presence in the cultural life of the city came in the period 1893-1906, once with the symphonic concerts of the conservatory orchestra, led by Eduard Caudella and Enrico Mezzetti, alongside choir concerts, conducted by Gavriil Musicescu, chamber music recitals ${ }^{174}$, most performances being held at the National Theatre ${ }^{175}$. The last production "given by the students of the Iaşi Conservatory" recorded by Alexandru Aurescu in the annual cited ${ }^{176}$ (of 19 June 1905) also contained opera performances (Act III of "Rigoletto" by Verdi) in its program. Since then, the conservatory's concert season was uninterrupted in the cultural life of the city of Iaşi, training and educating its public (the concerts were prefaced by conference), a phenomenon that, until the 1970s, shaped a musical education focused on interpretation.

\section{Conclusions}

The study shows that music education in the old capital of Moldova reflects diverse spiritual and cultural interpenetrations - Russian, Polish, Austrian, German, Italian, Greek and from other provinces of Romania - features that stimulated local tradition and created a constructive emulation. We may state that in the seventh and eighth decades of the 20th century, the "George Enescu” Conservatory reached a standing and value of a higher education music education institution of Europe of that time, its success was achieved by a group of professors educated in România in Iaşi, Bucharest and Cluj-Napoca. Openness to other musical and educational cultures would revive in 2000s

\footnotetext{
${ }^{174} \mathrm{Cf}$. Atena Elena Simionescu (editor), 155 years of Modern Artistic Education in Iasi. Part I, 1930-1950/155 years of modern artistic education in Iaşi.Part I, 1830-1950., chapter „Musical Art” (authors: Carmen Chelaru, Laura Vasiliu şi Dalia Rusu-Persic) Editura Artes, 2015, p. 40

${ }^{175} \mathrm{Cf}$. Alexandru Aurescu, op.cit., p.458-617

${ }^{176}$ Idem, p.617
} 
through the development of new programs. This research focused mainly on Byzantine religious music taught in Iasi using Greek methods and content by professors trained in Salonika (Thessaloniki) Athens and we also underlined the introduction of folk instruments (accordion, pan-flute) into the study program influenced by the music education tradition in Chişinau in the Republic of Moldova. The Western musical tradition also provided new models that have been put into practice in the program Jazz Composition and Pop Music.

The history of music education in Iasi reflects a high accumulation and assimilation of the European artistic tradition that had been sustained until the 1970s. Romanian compositions sometimes included in student concerts, the works of Romanian composers-teachers, elective courses introduced between the wars of the last century prepared the stage for the academic study of folk and psaltic traditions and later of modern music that combines academic research with interpretative practice.

Underlining the contribution of important personalities to the development of music school in Iasi, we focused both on the peculiarity of artistic education closely linked to figures of important professors who were also composers, singers and musicologists, and especially dealt with management instability of local and national music education. Also, the role undertaken by the Iasi Conservatory in supporting the musical life of the city until the opening of Philharmonic and Opera had been a noble mission but it also had put huge pressure on professors, students, directors to concentrate on musical interpretation and had delayed the development of composition and musicology in Iasi until the second half of the 20th century.

\section{References}

1. Aurescu, A. (1906). Anuarul Conservatorului de muzică şi declamaţie din Iaşi. De la înfiinţarea lui până la 1905, [Conservatory's Yearbook of Music and Declamation in Iaşi. Since its Foundation until 1905]. Iaşi: Tipografia H.Holdner

2. Cosma, O. \& Vasiliu, O. L. (2015). Spătărelu, Vasile. In Grove Music Online. Oxford Music Online. Oxford University Press. Web. 28 Nov. 2015. $<$ http://www.oxfordmusiconline.com/subscriber/article/grove/music/45002>

3. Cosma, O. \& Vasiliu, O. L. (2015). Pautza, Sabin. In Grove Music Online. Oxford Music Online. Oxford University Press. Web. 28 Nov. 2015. $<$ http://www.oxfordmusiconline.com/subscriber/article/grove/music/44993>

4. Cozmei, M. (2010). Pagini din istoria învăţământului artistic modern din Iaşi la 150 de ani [Pages in the History of Modern Artistic Education in Iasi at its 150th Anniversary]. Iași: Artes

5. Cozmei, M. (2005/2010). Existenţe şi impliniri. Dicţionar biobibliografic. Domeniul muzică [The Existence and Fulfillment. Bibliographical Dictionary. Music Field]. Iași: Artes

6. Duţică, L. (2015). Iulia Bucescu - Bases of Musical Teaching: Novelty Originality - Creativity. Review of Artistic Education, 9-10, 42-50 
7. Ghircoiaşiu, R. \& Vasiliu, O. L. (2015). Musicescu, Gavriil. In Grove Music Online. Oxford Music Online. Oxford University Press. Web. 28 Nov. 2015<http://www.oxfordmusiconline.com/subscriber/article/grove/music/194>

8. Pascu, G. (1964). 100 de ani de la infiinţarea Conservatorului "George Enescu"Iaşi (1864-1964) [100 Years since the Foundation of the "George Enescu" Conservatory in Iaşi]

9. Pascu, G. \& Sava, I. (1987). Muzicienii Iaşului [Musicians of Iasi]. București: Editura muzicală

10. Pascu, G. \& Boţocan, M. (1997). Hronicul muzicii ieşene [Chronicle of Music in Iasi]. Editura „Noël”

11. Pascu, G. (2015). Din dragoste de oameni şi de muzică. 14 convorbiri moderate de Mihail Cozmei şi Dora-Maria David [Out of Love for People and Music. 14 conversations moderated by Mihail Cozmei and Dora-Maria David]. Iași: Artes

12. Simionescu, A. E. (coord.) (2015). 155 ani de învăţământ artistic modern la Iaşi. Partea I, 1930-1950.Partea a II-a, 1950-2015 / 155 years of modern artistic education in Iaşi.Part I, 1830-1950. Part II. 1950-2015 [155 years of Modern Artistic Music Education in Iaşi. Part I, 1930-1950. Part II 1950-2015 / 155 years of modern artistic education in Iaşi]. Iași: Artes

13. Tetelea, M. (2015). National and Universal Trends in the Modern System of Music Education in Moldova. Review of Artistic Education, 9-10, 18-25

14. Vasiliu, O. L. (2015). Iaşi. In Grove Music Online. Oxford Music Online. Oxford University Press. Web. 14 Nov. 2015. $<$ http://www.oxfordmusiconline.com/subscriber/article/grove/music/40385> 15. Vasiliu, O. L. (2015). Munteanu, Viorel. In Grove Music Online. Oxford Music Online. Oxford University Press. Web. 28 Nov. 2015. $<$ http://www.oxfordmusiconline.com/subscriber/article/grove/music/2280569> 